\title{
BIOLOGICALLY STRUCTURED MATERIALS
}

\author{
Raffaella Aversa \\ Advanced Materials Lab, Department of Architecture and Industrial \\ Design, Second University of Naples, Italy \\ E-mail: raffaella.aversa@unina2.it \\ Relly Victoria Virgil Petrescu \\ IFToMM, Romania \\ E-mail: rvvpetrescu@gmail.com \\ Antonio Apicella \\ Advanced Materials Lab, Department of Architecture and Industrial \\ Design, Second University of Naples, Italy \\ E-mail: antonio.apicella@unina2.it \\ Florian Ion Tiberiu Petrescu
IFToMM, Romania
E-mail: fitpetrescu@gmail.com
}

Submission: $12 / 30 / 2018$

Revision: $2 / 8 / 2019$

Accept: 9/19/2019

\section{ABSTRACT}

Biomimetics, biomechanics, and tissue engineering are three multidisciplinary fields that have been contemplated in this research to attain the objective of improving prosthetic implants reliability. Since testing and mathematical methods are closely interlaced, a promising approach seemed to be the combination of in vitro and in vivo experiments with computer simulations (in silico). An innovative biomimetics and biomechanics approach, and a new synthetic structure providing a microenvironment, which is mechanically coherent and nutrient conducive for tissue osteoblast cell cultures used in regenerative medicine, are presented. The novel hybrid ceramic-polymeric nanocomposites are mutually investigated by finite element analysis (FEA) biomimetic modeling, anatomic reconstruction, quantitative-computedtomography characterization, computer design of tissue scaffold. The starting base materials are a class of innovative highly bioactive hybrid ceramicpolymeric materials set-up by the proponent research group that will be used as a bioactive matrix for the preparation of 
DOI: 10.14807/ijmp.v11i4.950

in situ bio-mineralized techno- structured porous nanocomposites. This study treats biomimetics, biomechanics and tissue engineering as strongly correlated multidisciplinary fields combined to design bone tissue scaffolds. The growth, maintenance, and ossification of bone are fundamental and are regulated by the mechanical cues that are imposed by physical activities: this biomimetic/biomechanical approach will be pursued in designing the experimental procedures for in vitro scaffold mineralization and ossification. Bio-tissue mathematical modeling serves as a central repository to interface design, simulation, and tissue fabrication. Finite element computer analyses will be used to study the role of local tissue mechanics on endochondral ossification patterns, skeletal morphology and mandible thickness distributions using single and multi-phase continuum material representations of clinical cases of patients implanted with the traditional protocols. New protocols will be hypothesized for the use of the new biologically techno-structured hybrid materials.

Keywords: Biotechnology; Bioengineering; Biomaterials, Bioactive scaffolds, biomimetics, Finite Element Analysis, Osteointegration, Osteoinduction

\section{INTRODUCTION}

The interdisciplinary research field of materials for biomedical applications is strongly based on the study of bone tissue repair.

Bone is considered a biological hybrid material composed of an organic component, collagen, and an inorganic nanocrystalline hydroxyapatite component. Both phases integrate each other at a nano-scale level in such a way that morphological and physical variables such as the crystallite size, the nanofibers orientation, the short range order between both components, determine its nanostructure features and, therefore, the functional and mechanical properties of the different types of bone (FROST, 1964; FROST,1990; FROST, 2004).

Based on the bone regeneration criteria, we developed new bio-active-biomaterials. These materials are expected to favour the bone tissue formation by fostering osteoblast proliferation and differentiation (SCHIRALDI et al 2004).

The use of materials with nanostructure similar to that of natural bone tissue is one of the most promising options in bone healing. Nanotechnologies for the implementation of organic-inorganic hybrid materials are providing excellent chances for improving the performance of the existing conventional bone implants (AVERSA et al., 2016a; AVERSA et al., 2016b; AVERSA et al., 2016c; AVERSA et al., 2016d; AVERSA et al., 2016e; AVERSA et al., 2016f; AVERSA et al., 2016g; AVERSA et al., 2016h; AVERSA et al., 2016i; AVERSA 
DOI: 10.14807/ijmp.v11i4.950

et al., 2016j; AVERSA et al., 2016k; AVERSA et al., 2016l; AVERSA et al., 2016m; AVERSA et al., 2016n; AVERSA et al., 2016o; AVERSA et al., 2017).

The present research evaluates the advances in nano-silicate-polymer hybrids for bone tissue repair, as well as the chemical procedures that allow controlling the material nanostructure.

The objective of the paper is inherent to the following scientific areas;

- Biomechanics and Biofidelity of human bone modelling,

- Biomimetics: nanotechnologies in medicine for nature inspired materials

- Bioactive Scaffolds favouring osteointegration in porous structural nanocomposite and hybrid matrices

\subsection{Biofidelity advances}

Recent studies on mandible (SCHWARTZ-DABNEY; DECHOW, 2003; APICELLA et al., 2010; AVERSA et al., 2009; AVERSA et al., 2016a; AVERSA et al., 2016b) and tooth FEM modelling (Sorrentino et al., 2007; Sorrentino et al., 2009; APICELLA et al., 2011; APICELLA et al., 2015; PETRESCU, 2018) suggest that biomechanics investigation of bones could be successfully applied to orthopaedics to provide a means for predicting the clinical results of implant based restoration procedures.

The knowledge of the mechanical and adaptive characteristics of bone is a critical issue in designing new biomimetic prostheses to replace a bone with minimal biological and biomechanical invasiveness.

Biomimetics is the science that investigates such aspects and it may be considered the natural junction between biology and engineering. This convergence of competence enables the development the biological principles and models needed to produce bio-inspired materials that can be used to fully engineer tissues and prosthetic systems.

New generations of concepts could be generated by conscious investigation of biomimetics, which can provide the clinical instruments to restore the structural, biomechanical, and aesthetic integrity of bone functions.

Recent technological advances in cells and molecular biology and in materials engineering science (nanotechnology) established that biomimetics and tissue engineering are emerging to help improving full integration of the restorative and prosthetic implants 
DOI: 10.14807/ijmp.v11i4.950

(AVERSA et al., 2009; AVERSA et al., 2016, PERILLO et al., 2010; ANNUNZIATA et al., 2006, APICELLA et al., 2010).

Since last century, several parts of our body have been replaced by artificial prostheses. The materials used for these devices were chosen to not produce adverse responses in contact with human body tissues and physiological fluids.

The criteria for the choice of a specific biomaterial were related to its biocompatibility and functionality, which could be directly associated to the bone/implant interfacial interactions at a nanoscale level. It is only from the 90's that the study of these interfacial effect has been improved by using thin nanomeric coatings and surface modifications.

It has been then generated a great commercial interest into the orthopaedic market to adopt new modified implants with surface nano-treatments promoting hard- and soft-tissue engineering (ANNUNZIATA et al., 2008; COMERUN, 1986; ČEPELAK, 2013; CHEN, 2013; CORMACK, 2012; HEINEMANN, 2013).

\subsection{New classes of Biomaterials}

There is several ways in which the living tissues can react to the synthetic materials of the implants but they are essentially confined to their responses to the material of the interface

Three main terms could describe biomaterials behaviour as defined by Jones et al (2012), Hutmacher (2000), and Hoppe (2011).

Namely, tissue responces are divided in:

- Bioinert

- Bioresorbable

- Bioactive

A further classification of ceramic based biomaterials can be made according to their reactivity to the physiological fluids;

- bioinert, such is the Alumina for dental application),

- bioactive, such is the hydroxyapatite used as coating on metal implants,

- $\quad$ surface active, such are the bio-glass or the A-W glasses,

- bio-resorbed, such is the tri-calcium phosphate 
DOI: 10.14807/ijmp.v11i4.950

Further improvement of these material properties can be achieved using nano structured bioceramics that can potentially be used as interactive materials, helping the tissue natural tendency to heal by promoting tissues regeneration and restoration of physiological functions (SCHIRALDI et al., 2004; MANO et al., 2004; MORALES-HERNANDEZ et al., 2012; MOURIÑO et al., 2012).

This approach has been investigated in this study with the aim to develop a new generation of nano-structured bio-ceramo-polymeric hybrids that can be used in a more extended range of medical applications (PETRESCU; CALAUTIT, 2016a; PETRESCU; CALAUTIT, 2016b; PETRESCU et al., 2015; PETRESCU et al., 2016a; PETRESCU et al., 2017b; PETRESCU et al., 2017c; PETRESCU et al., 2017d; PETRESCU et al., 2017e; PETRESCU et al., 2017e; PETRESCU et al., 2018).

Porosity is one of the key of success of these materials and it is increasing adopted when bone natural ingrowth, and strong implant stability are needed.

\subsection{Tissue engineering new perspectives}

Since few years, tissue engineering is taking benefit from the combined use of living stem cells seeding in tri-dimensional ceramic scaffolds. This strategy is finalized to supply healthy cells directly in the damaged place (BONFIELD et al., 1981; HENCH, 1993; HENCH, 2002; HENCH, 2010).

By combining the traditional bio-ceramics implant, with the already assimilated knowledge of stem cells growth and differentiation into osteogenic one, clinical practicable and productive strategies have been developed.

Cultured stem-cells in ceramic nano-biocomposites could be adopted in the case extended bone repair with excellent perspectives good functional recovery and integration of the hybrid scaffold with bone.

Synthetic hydroxyapatite (HAp) has been described in literature as an attractive material for bone implants (KIM et al., 2004; MORALES-HERNANDEZ et al., 2012).

Since its adoption, the most used and simplest method of production for the synthetic HAp is the solid-state reaction between Calcium and Phosphate ions, leading to the formation of compounds in the form of powders that can be sintered and high temperature annealed to form a compact polycrystalline structure (JULIEN, 2007). 
DOI: 10.14807/ijmp.v11i4.950

The bioactivity of HAp is governed by processing parameters such as the starting compounds crystal grain size, their purity and the ratio between Calcium and Phosphorous atoms. In particular, nano-crystals have shown an improved bioactivity that was due to increased surface area. The use of nano-particulated Hydroxyapatite has been proposed as a valid solution for reinforcement of low strength polymeric scaffolds.

By using nanoparticulated HAp new classes of implants biocompatible coatings and high-strength nanocomposites can be developed (GORUSTOVICH et al., 2010).

\subsection{Biomimetics}

A characteristic feature of several natural tough hybrid materials, such are bone, sea urchin tooth, nacre, is the strong interaction at nanoscale level between the inorganic and the organic phases. This characteristic allows the organic phase to act at nanoscale level as a plastic highly energy-dissipating network that inhibit crack propagation (high resiliency); s, in situ synthesis techniques have been adopted to mimic the naturally occurring processes. In particular, the precipitation of hydroxyapatite (or other crystalline compound) into a polymeric matrix has been considered a viable route to produce biomimetic composites.

\subsection{Organic-Inorganic Hybrid Biomaterials}

A bioinspired material development approach considering the formation of selfassembling hybrid organic-inorganic will favour the use of hybrids in biomedical applications. The high versatility of these hybrids offers main functional and structural advantages that lead to the possibility to tailor-design materials in terms of shape, and chemical and physical properties.

\subsection{Bioengineering and Bioactive scaffolds}

For micro and nano-materials bioengineering, nanotechnology is being increasingly adopted for emerging applications such as coatings or three-dimensional (tecto) scaffolds (AVERSA et al., 2016a; KARAGEORGIOU et al., 2005; SORRENTINO et al., 2007). Decisively, micro and nano-technologies show potentiality to be used to manufacture advanced models for fundamental studies, such as ordered tissue engineered structures or bio-molecular devices.

Ideal bone scaffolding material has been always a hot topic for research. An ideal scaffold should provide a sufficiently rigid but resilient network to temporarily substitute the damaged bone. At the same time it should be able to biodegrade after the new tissue formation 
DOI: 10.14807/ijmp.v11i4.950

and fully integrate with it (MONTHEARD et al., 1992; KABRA et al., 1991; PELUSO et al., 1997, SCHIRALDI et al., 2004).

Highly-bioactive amorphous fumed silica nano-composites have been synthesised in our laboratory. A new class of hybrid polymeric-ceramic materials mimicking the mechanical behaviour of the bone have been used as a potential candidate scaffolding material.

The resulting these self-assembled nanostructured composite have been micro-foamed and tested as new perimplantar scaffold that can host osteoblast grow factors or stem cells for osteoblasts differentiation.

\subsection{Biofidelity models and FEM analysis}

The understanding of the biological mechanisms of healthy bone dynamic growth is an iterative process between biology and engineering. During this process, the knowledge that the reverse engineering of a biological system can bring can have a positive feedback into biology, allowing a more complete and certain understanding of the potential route of further developments in medical applied engineering.

The most important question is how the clinician's interference with the biological systems can be optimized in order to improve treatment modalities in such a way that efficiency of treatment is increased and that it leads to a more stable outcome.

The use of newly developed combined diagnostic and engineering tools, such as those utilised in our research (i.e. maxillo-facial district NMR or CT segmentation and solid CAD reconstruction) can detail the anatomy of hard and soft textures in an extremely precise way with smallest standard deviations. The integration of biological knowledge and clinical possibilities is thus essential. A more reliable and biofidel model begins with the biomechanical modelling of a bones, ligament, and alveolar bone, using Finite Element Analysis in order to gain insight into the biological response to changing biomechanical circumstances.

Since current testing and numerical methods are closely interlaced, an auspicious methodological approach is to combine in vitro and in vivo experiments with computer simulations (in silico). There are, however, a number of stimulating points involved in creating the mathematical model and its realization. The concurrent interaction of the several variables influencing the prosthetic system has been investigated by means of simulation in finite element mathematical modelling. 
DOI: $10.14807 /$ ijmp.v11i4.950

The finite element analysis (FEA) involves the subdivision of a geometrical model into a finite number of elements, each of them with specific mechanical properties. The variables to investigate are guessed with mathematical functions. Specific mathematical software evaluate the distribution of stresses and strains as a response to changing loading conditions.

A complete evaluation of the mechanical behaviour of a sound or prothesized biologic structure is achievable, even in non-homogeneous bodies. When opportunely validated by in vivo or in vitro tests, the Finite Element Analysis is useful in defining optimum restorative design and material choice criteria, while enabling the prognostication of potential fracture under limiting given circumstances.

\section{METHODS AND MATERIALS}

\subsection{Materials}

2-hydroxyethyl methacrylate (HEMA), Sigma-Aldrich Chemicals Co., (St. Louis, MO, USA) has been used as hydrophilic matrix for fumed amorphous silica filler (Aerosil 300 Degussa, Germany) with a mean diameter of $7 \mathrm{~nm}$ with a specific surface area of $300 \mathrm{~m} 2 \cdot \mathrm{g}-1$. The initiator of the radical polymerization reactions used was the $\alpha-\alpha$ ' azoisobutyrronitrile (AIBN), obtained from Fluka (Milan, Italy). HEMA monomers were mixed with the fumed silica in the ratio of $10 \%$, by volume. The degassed resin was poured in $2.5 \mathrm{~mm}$ thick flat moulds and polymerized at oven controlled temperature of $60^{\circ} \mathrm{C}$ for $24 \mathrm{~h}$. A final post-cure of $1 \mathrm{~h}$ at $90^{\circ} \mathrm{C}$ was finally done on the nanocomposites sheets.

Micro porosity has ben induced in the dense material by first equilibrating the samples in pure ethyl alcohol and then fast extraction of the absorbed alcohol by equilibration in distilled water. During the fast alcohol extraction and counter diffusion, a micro porosity is generated in the hybrid ceramo-polymeric material, which was made evident by an intense whitening of the treated system.

\subsection{Finite Element Analysis (FEA) modelling}

Medical Image Segmentation has been derived from CT using the Mimics software (Materialise, Belgium) to process a patient medical image. As reported in the upper part of Figure 1, processing of CT resulted in a highly accurate 3D solid model of the bone anatomy and structure.

A combined use of Mimics and 3-Matic (Materialise, Belgium) software's has been use to derived 3D solid and Finite Element Analysis models (FEA). 
DOI: 10.14807/ijmp.v11i4.950

The external geometry of the bone has been reconstructed by generating a threedimensional volume that interpolates the CT scans. The results were then imported in the 3Matic software for surface and solid meshing optimization, Finite element model preparation and material properties assignation to the different sections of the bone according to the literature characteristics (BEAUPRE; HAYES, 1985; REILLY; BURNSTAIN, 1974; REILLY; BURNSTAIN, 1975; HUISKES et al., 1987; SCHWARTZ; DECHOW, 2003; TÖYRÄSA et al., 2001).

\section{RESULTS AND DISCUSSION}

Stresses on the bone can be modulated by scaffold swelling thickness choice for healthy bone growth. In vivo tests performed using these new modified oral implant confirmed the improved capability of such implants in promoting early osseointegration (GRAMAZZINI et al., 2016; MIRSAYAR et al., 2017).

Biomimetic/Biomechanical approach: Hybrid ceramo-polymeric surface and bulk properties design for osteointegration improvement

Bio-prosthetic devices represent a reconstructive therapy widely used in clinical practice in many fields of rehabilitative surgery as dentistry, maxillo-facial surgery, orthopaedics. The interface between bone and implant is subject of study for many years, because we are trying to pass from bioinert to bioactive biomaterials. In fact histological analysis done in these years don't allow to confirm theories about a possible contact, through junction systems and other.

But there is a fluid contact between osteocytic canalicula and implant surface. Bioactive biomaterials could favour and enhance the differentiation toward an osteoblastic fenotype, that becomes during the surgical wound healing caused by the implant, so having a better osseointegration in shorter times. Recent studies describe the features of some nanostructured materials that could promote osseointegration:

- Carbonium and alumina nanostructures, which mime the nano-dimensional geometry of hydroxyapatite, enhance the osteoblastic activity and so produce a greater bone deposition when applied to orthopedic implants.

- Nanostructured biomaterials, which mime the hydroxyapatite crystal bioactivity, promote the adhesion and the production of alkaline phosphates in osteoblasts-like cells 
DOI: 10.14807/ijmp.v11i4.950

So further studies on these materials could bring to a better and shorter healing, to promote protocols that provide early and immediate loading. The composition and surface properties seem to be important since they appear to modulate osteoblastic cells response affecting tissue healing (DAVIS et al., 1991; GRAMAZZINI et al., 2016; AVERSA, 2016b).

The peri-implant tissue adjusts its composition and architecture in relation to its functional load bearing (APICELLA et al., 2011; APICELLA et al., 2015). Therefore, one key to success of the Titanium implant to integrate within the bone seems to be whether or not the bone adequately remodels at the periphery of the implant (AVERSA et al., 2016b).

Figure 1 reports the result of the "in vivo" experiments carried out on dental implants placed in white rabbit femour. In particular, the experiment described in Aversa et al (2016b) consisted in the evaluation of osteoinductivity and osteoconductivity of the surfaces of $\mathrm{Ti}$ implants without and with a 100 microns thin coating of our ceramo-polymeric hybrid material. The bone implant apposition or bone ingrowth (COMERON 1986), which is defined as the percentage of osteointegrated implant length for the biomimetically coated and uncoated implants in the six months in vivo test show a significant improvement of about $100 \%$ increase in the first two months and of the $30 \%$ after 6 months.

Micro-CT bone reconstruction of the bone ingrowth around the implant was validated by the use of FEA calculated physiological strain distributions. The colored strain maps around in the bone surrounding the implant confirmed the critical role of the bioactive Ti-Bone interface.

The Osteoblast proliferation and bone growth in the implanted rabbit femur is clearly favoured and accelerated by the presence of the hybrid nanostructured coating.

The biomechanical approach using the adaptive properties of bone well describes the biomimetic behaviour of the proposed perimplantar hybrid scaffold since it can predict areas of bone reabsorption (FEA model elements with strains below the physiological lower limits have been removed in the image), as it occurs in the in vivo tests at the neck of the implant (Micro CT reconstruction on the right side of figure 1). 
DOI: $10.14807 /$ ijmp.v11i4.950

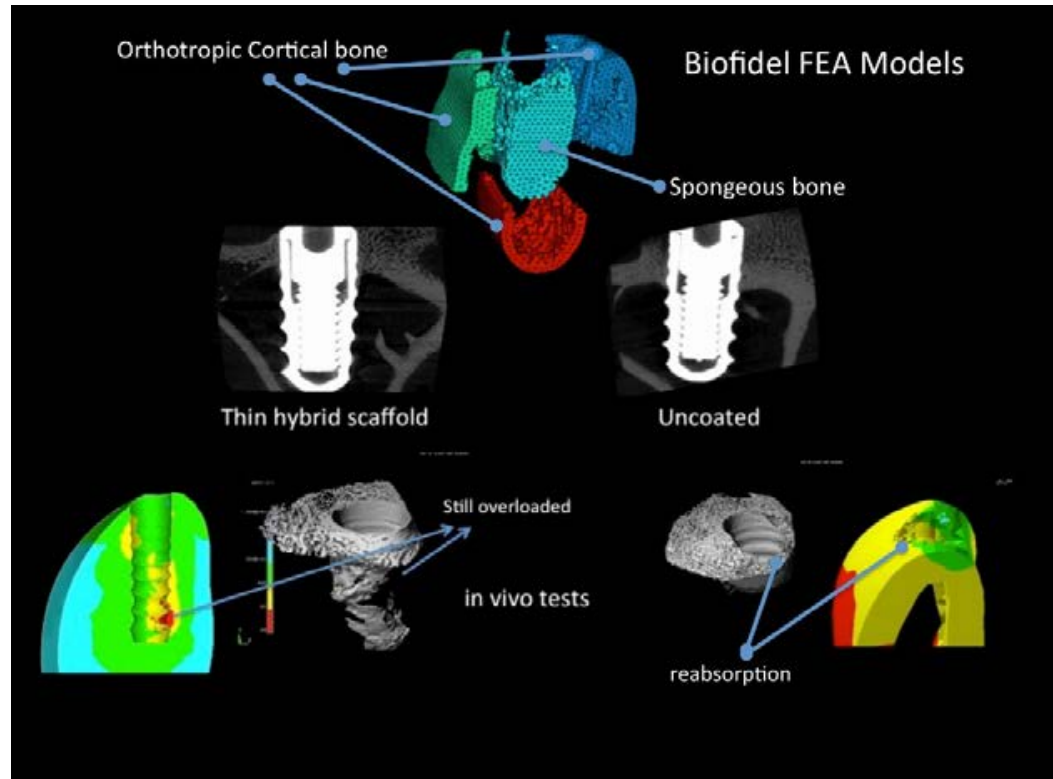

Figure 1: in silico and in vivo validation for Osteoconduction of Titanium implants coated with a nanostructured hybrid osteoactive (left side) and without (right).

Research has shown that mechanical stimulation can have a profound effect on the differentiation and development of mesenchymal tissues.

Figure 2 illustrates the adaptive properties and strain threshold values for healthy bone growth. According to Frost (1990), who quantified the observations of Wolff (1892), above (>3000 microepsilon) and below (<50 microepsilon) critical strain levels, bone growth is impaired. In the mild range of strains, healthy bone growth and regeneration is favoured. In fact, in order too maintain the stability of implants under load, it is of major importance for the bone-forming osteoblast to promote extra-cellular matrix in the vicinity of the implant. Osseointegration mechanisms to account for in the biofidel models

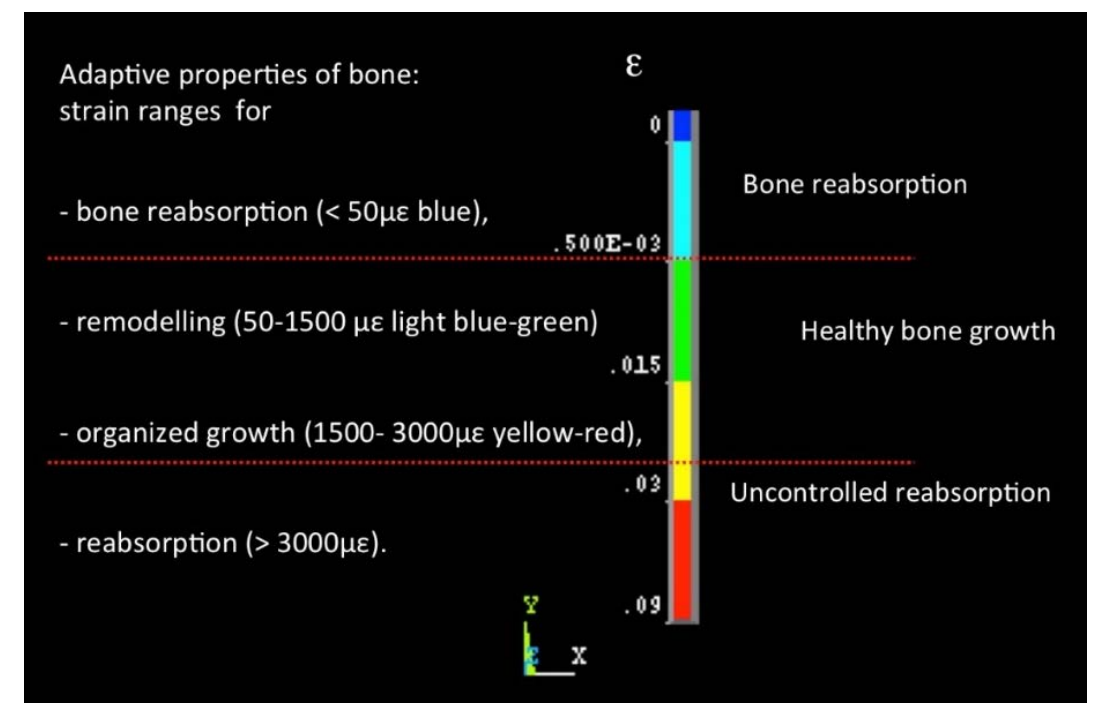

Figure 2: adaptive window of bone physiology: Structural adaptations to mechanical usage Source: Frost (1990) 
DOI: 10.14807/ijmp.v11i4.950

The osseointegration of the implants is essential for the attainment of prosthetic rehabilitations. The accomplishment and the maintenance of a stable functional anchilosis show the following morpho-structural features, namely:

- Direct contact between bone and implant, in absence at the interface of idoneous tissues;

- the existence of primary bone in contact with the surface of the biomaterial;

- deposition, externally to the primary bone layer, of lamellar secondary bone in contact with the titanium surface;

- total increase of the perimplantar osseous density compared to the normal bone architecture of the region;

- growth of medullar spaces, which is necessary to exhaust the metabolic requirement of the tissue in the region less involved in the loading dissipation;

- Condensation of compact bone, which can be linked to the loading propagation patterns determined by the specific implant morphology;

- Organization of strong trabecular structure departing radiallly from compact perimplantar bone;

- Presence of a osseous crestal wall at level of the subepitelial connective, which can allow junctional trophism of and sulcular epithelium formation.

The mature mineralised matrix that has been described to occur in dental and orthopaedic clinical studies, is expected to assure the mechanical stability of the implant even in the early osseointegration phase (primary stability). In fact, due to the hydrophilic nature of the hybrid material, high levels of fluids are absorbed from the liquid external environment leading to significant swelling and volume increase of the initially glassy hybrid material (figure 3).

The biomimetic and bio-mechanically active scaffold is, therefore, accomplishing two biomechanical functions, the first is strictly related to the prosthetic system stabilization after implantation (the prosthesis can be early loaded one hour after implantation), while the second function is associated to the bone growth stimulus exerted bone area surrounding the implantation. 
DOI: 10.14807/ijmp.v11i4.950

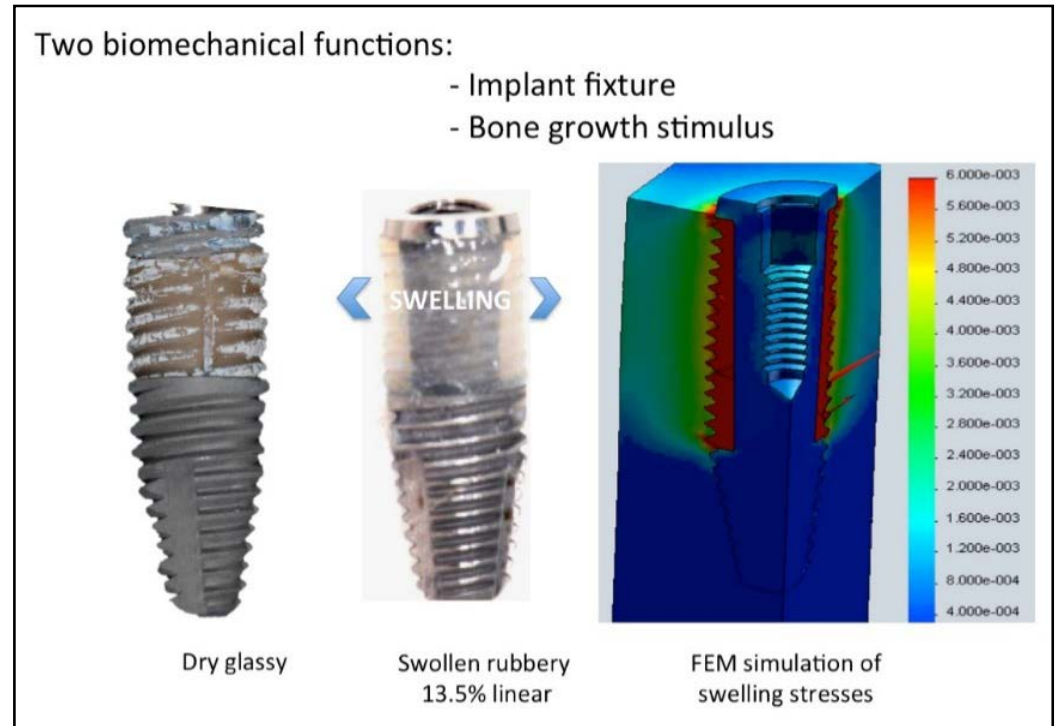

Figure 3: Mechanisms of primary stability and osteoinduction improvements in Hybrid swellable scaffold modified Titanium implant. Glassy dry scaffold (left)

The volumetric expansion of the scaffolds may be effective in improving the primary stability of the implants, confirming the high bioactive performance of the tested nanocomposite material (figure 4).

The presence of the swellable implant component contiguous the upper the Ti core of the implant increases its removal torque after implantation when the system is in presence of organic fluids.

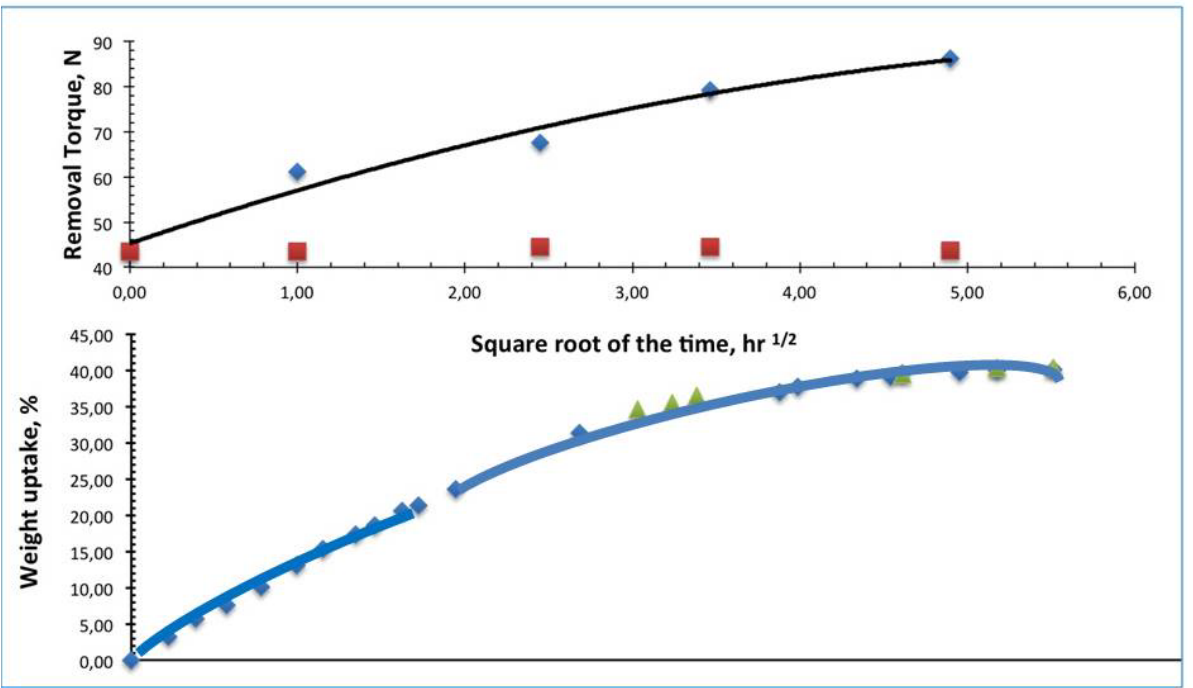

Figure 4: Physiological fluid uptake (bottom) and implant stability improvement (top) of Hybrid swellable scaffold modified Titanium implant.

The removal torque measured at different times after implantation, in fact, increased of more than $100 \%$ at 24 . Moreover, even just after one hrs, the removal torque already raised 
DOI: 10.14807/ijmp.v11i4.950

from 43 to $62 \mathrm{~N}$ (about 25\% improvement). It has been described in a previous paper (AVERSA et al., 2016b) that the retention improvement was directly following the swelling kinetic of the hybrid material scaffold (lower part of figure 4).

This increase of the implant stability is due to the strong compressive strains generated in the swollen rubbery hybrid scaffold as it can be inferred from the colored strains map reported in the right side of figure 3 (red color of the hybrid insert of the implant). The implant is then constrained in its socket by the external bone, which then increases the retention and stability of the implant. The application of a higher removal torque for explanting is therefore needed at increasing swelling levels, as indeed it has been experimentally measured. Moreover, the constraining bone is subjected to expansion strains as indicated by the Von Mises strains colored map reported in the right hand side of figure 3. The color scale utilized for this map is the same of that reported in figure 2, namely, the adaptive window of bone physiology where healthy bone growth and induction corresponds to the colors yellow and green and blue and red to bone reabsorption.

The surrounding bone is subjected to a healthy bone physiological deformation for a distance equivalent to the implant diameter. In this toroid volume surrounding the implant, then, it would be expected an osteoinductive effect and more rapid implant osteointegration. A micro Computer Tomography has confirmed these expectations. Figure 5 shows the micro CT of these volumes.

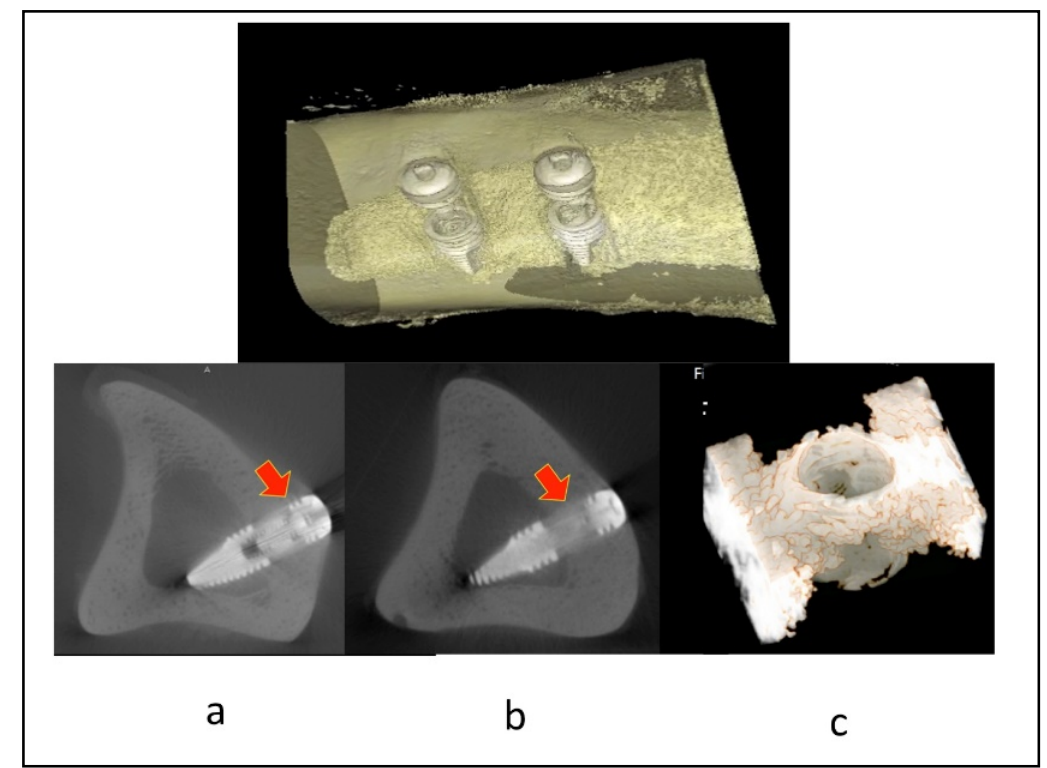

Figure 5: The Bone to Implant Contact (BIC) and the relative bone density have shown similar characteristics at cortical (a) and medullar levels (b), Bone near to the implants shows similar characteristics (c) Source: Gramanzini et al. (2016) 
DOI: 10.14807/ijmp.v11i4.950

In the upper part of the figure is reported the external volumetric reconstruction of the bone and implants while in the lower part it is shown the 3D reconstruction of the volume surrounding one implant.

The Bone Implant Contact (BIC) and the relative bone density have shown similar characteristics at cortical (a) and medullar levels (b) indicating a good implant osteointegration with the original bone. The newly formed bone near to the implants surprising shows characteristics similar to the previous one (c), indicating that a biomechanichally stimulating effect of the swollen hybrid scaffolding material.

\section{CONCLUSIONS}

It is necessary to develop new technologies in biomaterials field, in order to obtain scaffolds and bone substitutes that could have a fundamental role in bone regeneration. It is requested to bone scaffolds to show particular intrinsic characteristics in order to work as a real bone substitute that satisfies biological, mechanical and geometrical constrains. Such features comprise:

- Biological requirements - the computed scaffolds must enable cell adhesion and homogeneous distribution, growth of regenerative tissue, and assist the passage of nutrients and chemical signals. This achievement has been attained by controlling the porosity of the scaffold;

- Mechanical requirement - the estimated scaffolds must preserve the mechanical and toughness properties that allow osteoblasts colonies to experience physiological and bioactive controlled deformations. This has been achieved by properly modifying the hybrid ceramo-polymeric compositional ratio (in our case, $10 \%$ by volume of amorphous nano-silica).

Combined clinical observation of traditional implant behaviour will be used to validate the biofidelity of the FEM models, while comparison between in vitro and computer aided simulation of osteoblast colony growth can then allow us to explore many novel ideas in modelling, design and fabrication of new nanostructured scaffolds with enhanced functionality and improved interaction with cells. This turns particularly useful in designing and directly manufacturing complex bone tissue scaffolds. 
INDEPENDENT JOURNAL OF MANAGEMENT \& PRODUCTION (IJM\&P)

http://www.ijmp.jor.br

v. 11, n. 4, July - August 2020

ISSN: 2236-269X

DOI: $10.14807 /$ ijmp.v11i4.950

\section{ACKNOWLEDGEMENT}

This text was acknowledged and appreciated by Assoc. Pro. Taher M. Abu-Lebdeh, North Carolina A and T State Univesity, United States, Samuel P. Kozaitis, Professor and Department Head at Electrical and Computer Engineering, Florida Institute of Technology, United States.

\section{FUNDING INFORMATION}

This research has been funded by Italian Ministry of University and Research project FIRB Future in Research 2008 project RBFR08T83J.

\section{REFERENCES}

ANNUNZIATA, M.; AVERSA, R.; APICELLA, A.; ANNUNZIATA, A.; APICELLA, D.; BUONAIUTO, C.; GUIDA, L. (2006) In vitro biological response to a light-cured composite when used for cementation of composite inlays, Dental Materials, v. 22, n. 12, p. 10811085. DOI: 10.1016/J.DENTAL.2005.08.009

ANNUNZIATA, M.; GUIDA, L.; PERILLO, L.; AVERSA, R.; I. PASSARO, I. (2008) Biological response of human bone marrow stromal cells to sandblasted titanium nitridecoated implant surfaces. J. Mater. Sci. Mater. Med.; v. 19, p. 3585-3591. DOI: 10.1007/s10856-008-3514-2.

APICELLA, D.; AVERSA, R.; FERRO, E.; IANNIELLO, D.; APICELLA, A. (2010) The importance of cortical bone orthotropicity, maximum stiffness direction and thickness on the reliability of mandible numerical models, Journal of Biomedical Materials Research -

Part B Applied Biomaterials, v. 93, n. 1, April, p. 150-163 (8, p. doi: 10.1002/jbm.b.31569

APICELLA, D.; VELTRI, M.; BALLERI, P.; APICELLA, A.; FERRARI, M. (2011)

Influence of abutment material on the fracture strength and failure modes of abutment-fixture assemblies when loaded in a bio-faithful simulation, Clinical Oral Implants Research, v. 22, n. 2, February, p. 182-188: DOI: 10.1111/j.1600-0501.2010.01979.x

APICELLA, D.; AVERSA, R.; TATULLO, M.; SIMEONE, M.; SAYED, S.; MARRELLI, M.; APICELLA, A. (2015) Direct restoration modalities of fractured central maxillary incisors: A multi-levels validated finite elements analysis with in vivo strain measurements, Dental Materials, v. 31, n. 12, 1 December, p. e289-e305, DOI: 10.1016/j.dental.2015.09.016

AVERSA, R.; APICELLA, D.; PERILLO, L.; SORRENTINO, R.; ZARONE, F.; FERRARI, F.; APICELLA, A. (2009) Non-linear elastic three-dimensional finite element analysis on the effect of endocrown material rigidity on alveolar bone remodeling process. Dental materials, v. 25, p. 678-690: DOI: 10.1016/j.dental.2008.10.015

AVERSA, R.; PETRESCU, F. I. T.; PETRESCU, R. V.; APICELLA, A. (2016a) Biomimetic FEA bone modeling for customized hybrid biological prostheses development. Am. J.

Applied Sci.; v. 13, p. 1060-1067. DOI: 10.3844/ajassp.2016.1060.1067

AVERSA, R.; PARCESEPE, D.; PETRESCU, R. V.; CHEN, G.; PETRESCU, F. I. T.; TAMBURRINO, F.; APICELLA, A. (2016b) Glassy Amorphous Metal Injection Molded Induced Morphological Defects, Am. J. Applied Sci.; v. 13, n. 12, p. 1476-1482. 
AVERSA, R.; PETRESCU, R. V.; PETRESCU, F. I. T.; APICELLA, A. (2016c) SmartFactory: Optimization and Process Control of Composite Centrifuged Pipes, Am. J. Applied Sci.; v. 13, n. 11, p. 1330-1341.

AVERSA, R.; TAMBURRINO, F.; PETRESCU, R. V.; PETRESCU, F. I. T.; ARTUR, M.; CHEN, G.; APICELLA, A. (2016d) Biomechanically Inspired Shape Memory Effect Machines Driven by Muscle like Acting NiTi Alloys, Am. J. Applied Sci.; v. 13, n. 11, p. 1264-1271.

AVERSA, R.; BUZEA, E. M.; PETRESCU, R. V.; APICELLA, A.; NEACSA, M.; PETRESCU, F. I. T. (2016e) Present a Mechatronic System Having Able to Determine the Concentration of Carotenoids, Am. J. of Eng. and Applied Sci.; v. 9, n. 4, p. 1106-1111.

AVERSA, R.; PETRESCU, R. V.; SORRENTINO, R.; PETRESCU, F. I. T.; APICELLA, A. (2016f) Hybrid Ceramo-Polymeric Nanocomposite for Biomimetic Scaffolds Design and Preparation, Am. J. of Eng. and Applied Sci.; v. 9, n. 4, p. 1096-1105.

AVERSA, R.; PERROTTA, V.; PETRESCU, R. V.; MISIANO, C.; PETRESCU, F. I. T.; APICELLA, A. (2016g) From Structural Colors to Super-Hydrophobicity and Achromatic Transparent Protective Coatings: Ion Plating Plasma Assisted TiO2 and SiO2 Nano-Film Deposition, Am. J. of Eng. and Applied Sci.; v. 9, n. 4, p. 1037-1045.

AVERSA, R.; PETRESCU, R. V.; PETRESCU, F. I. T.; APICELLA, A. (2016h) Biomimetic and Evolutionary Design Driven Innovation in Sustainable Products Development, Am. J. of Eng. and Applied Sci.; v. 9, n. 4, p. 1027-1036.

AVERSA, R.; PETRESCU, R. V.; APICELLA, A.; PETRESCU, F. I. T. (2016i)

Mitochondria are Naturally Micro Robots - A review, Am. J. of Eng. and Applied Sci.; v. 9, n. 4, p. 991-1002.

AVERSA, R.; PETRESCU, R. V.; APICELLA, A.; PETRESCU, F. I. T. (2016j) We are Addicted to Vitamins C and E-A Review, Am. J. of Eng. and Applied Sci.; v. 9, n. 4, p. 1003-1018.

AVERSA, R.; PETRESCU, R. V.; APICELLA, A.; PETRESCU, F. I. T. (2016k) Physiologic Human Fluids and Swelling Behavior of Hydrophilic Biocompatible Hybrid CeramoPolymeric Materials, Am. J. of Eng. and Applied Sci.; v. 9, n. 4, p. 962-972.

AVERSA, R.; PETRESCU, R. V.; APICELLA, A.; PETRESCU, F. I. T. (2016l) One Can Slow Down the Aging through Antioxidants, Am. J. of Eng. and Applied Sci.; v. 9, n. 4, p. 1112-1126.

AVERSA, R.; PETRESCU, R. V.; APICELLA, A.; PETRESCU, F. I. T. (2016m) About Homeopathy or «Similia Similibus Curentur», Am. J. of Eng. and Applied Sci.; v. 9, n. 4, p. 1164-1172.

AVERSA, R.; PETRESCU, R. V.; APICELLA, A.; PETRESCU, F. I. T. (2016n) The Basic Elements of Life's, Am. J. of Eng. and Applied Sci.; v. 9, n. 4, p. 1189-1197.

AVERSA, R.; PETRESCU, F. I. T.; PETRESCU, R. V.; APICELLA, A. (20160) Flexible Stem Trabecular Prostheses, Am. J. of Eng. and Applied Sci.; v. 9, n. 4, p. 1213-1221.

AVERSA, R.; PETRESCU, R. V. V.; APICELLA, A.; PETRESCU, F. I. T. (2017) Modern Transportation and Photovoltaic Energy for Urban Ecotourism. TRANSYLVANIAN

REVIEW OF ADMINISTRATIVE SCIENCES Special n.; p. 5-20. DOI: 10.24193/tras.SI2017.1

BEAUPRE G. S.; HAYES W. C. (1985) Finite Element Analysis of a three dimensional 
open-celled model for trabecular bone. J. Biomech. Eng.; v. 107, p. 249-56, PMID: 4046566 BONFIELD, W.; GRYNPAS, M. D.; TULLY, A. E.; BOWMAN, J.; ABRAM, J. (1981) Hydroxyapatite reinforced polyethylene - a mechanically compatible implant material for bone replacement. Biomaterials, v. 2, p. 185-186. DOI: 10.1016/0142-9612(81)90050-8

COMERUN, H. U. (1986) Six-year results with a microporous-coated metal hip prosthesis, Clin. Orthop. 20881

ČEPELAK I.; DODIG, S.; ČULIĆ, O. (2013) Magnesium-more than a common cation. Med. Sci., v. 39, p. 47-68.

CHEN, Q.; ZHU, C.; THOUAS, G. A. (2012) Progress and challenges in biomaterials used for bone tissue engineering: Bioactive glasses and elastomeric composites. Progress.

Biomater., v. 1, n. 1-22. DOI: 10.1186/2194-0517-1-2

CORMACK, A. N.; TILOCCA, A. (2012) Structure and biological activity of glasses and ceramics. Philos. Trans. Math. Phys. Eng. Sci., v. 370, p. 1271-1280. DOI: 10.1098/rsta.2011.0371

DAVIS, P. A.; HUANG, S. J.; NICOLAIS, L.; AMBROSIO, L. (1991) Modified PHEMA Hydrogels. In: Szycher M, editor. High performance biomaterials. Lancaster, PA, USA:

Technonic. p. 343-68.

PRASHANTHA, K.; VASANTH, K. P. K.; SHERIGARA, B. S.; PRASANNAKUMAR, S. (2001) Interpenetrating polymer networks based on polyol modified castor oil polyurethane and poly-(2-hydroxyethylmethacrylate, p. synthesis, chemical, mechanical and thermal properties, bull. Mater Sci., v. 24, n. 5, p. 535-8.

FILMON, R.; GRIZON, F.; BASLIE, M. F.; CHAPPARD, D. (2002) Effects of negatively charged groups (carboxymethyl) on the calcification of poly(2-hydroxyethylmethacrylate). Biomaterials, v. 23, p. 3053-9.

FROST, H. M. (1964) Mathematical elements of lamellar bone remodeling. Springfield: Charles C Thomas. p. 22-25.

FROST, H. M. (1990) Structural adaptations to mechanical usage (SATMU). 2. Redifining Wolff's law: the bone remodelling problem. Anat Rec, v. 226, p. 414-22.

FROST, H. M. (2003) update of bone physiology and Wolff's law for clinicians. Angle Orthod, v. 74, p. 3-15.

FROST, H. M. (1994) Wolff's law and bone's structural adaptations to mechanical usage: an overview for clinicians. Angle Orthod, v. 64, p. 175-88.

GRAMANZINI, M.; GARGIULO, S.; ZARONE, F.; MEGNA, R.; APICELLA, A.; AVERSA, R.; SALVATORE, M.; MANCINI, M.; SORRENTINO, R.; BRUNETTI, A.; (2016) Combined microcomputed tomography, biomechanical and histomorphometric analysis of the peri-implant bone: A pilot study in minipig model. Dental Materials, v. 32, n. 6, p. 794-806: DOI: 10.1016/j.dental.2016.03.025

GORUSTOVICH, A. A.; ROETHER, J. A.; BOCCACCINI, A. R. (2010) Effect of bioactive glasses on angiogenesis: A review of in vitro and in vivo evidences. Tissue Eng. Part B Rev., v. 16, p. 199-207. DOI: 10.1089/ten.TEB.2009.0416

HALPIN J. C.; KARDOS J. L. (1976) Halpin-Tsai equations: A review, Polymer Engineering and Science, v. 16, n. 5, p. 344-352 
INDEPENDENT JOURNAL OF MANAGEMENT \& PRODUCTION (IJM\&P)

http://www.ijmp.jor.br

v. 11, n. 4, July - August 2020

ISSN: 2236-269X

DOI: 10.14807/ijmp.v11i4.950

HEINEMANN, S.; C. HEINEMANN, S.; WENISCH, V.; ALT; WORCH, H. (2013)

Calcium phosphate phases integrated in silica/collagen nanocomposite xerogels enhance the bioactivity and ultimately manipulate the osteoblast/osteoclast ratio in a human co-culture model. Acta Biomaterialia, v. 9, p. 4878-4888. DOI: 10.1016/j.actbio.2012.10.010

HENCH, L. L.; POLAK, J. M. (2002) Third-generation biomedical materials. Science, n. 295, p. 1014-1017. DOI: 10.1126/science.1067404

HENCH, L. L.; THOMPSON, I. (2010) Twenty-first century challenges for biomaterials. J. Royal Society Interface, v. 7, p. S379-S391. DOI: 10.1098/rsif.2010.0151.focus

HENCH, L. L.; WILSON, J. (1993) An introduction to bioceramics. World Sci., v. 1, p. 396396. DOI: $10.1142 / 2028$

HOPPE, A.; GÜLDAL, N. S.; BOCCACCINI, A. R. (2011) A review of the biological response to ionic dissolution products from bioactive glasses and glass-ceramics.

Biomaterials, v. 32, n. 2757-2774. DOI: 10.1016/j.biomaterials.2011.01.004

HUISKES, R.; WEINANS, H.; GROOTENBOER, H. J.; DALSTRA, M.; FUDULA, B.; SLOOFF, T. J. (1987) Adaptive bone remodeling theory applied to prosthetic-design analysis. J Biomech, v. 20, p.1135-1150.

HUTMACHER, D. W. (2000) Scaffolds in tissue engineering bone and cartilage.

Biomaterials, v. 21, p. 2529-2543. DOI: 10.1016/S0142-9612(00)00121-6

JONES, J. R.; CLARE, A. G. (2012) Bio-Glasses. An Introduction. 1st Edn.; Wiley, Chichester, ISBN-10: 1118346475, p: 320.

JULIEN, M.; MAGNE, D.; MASSON, M.; ROLLI-DERKINDEREN, M.; CHASSANDE, O. (2007) Phosphate stimulates matrix Gla protein expression in chondrocytes through the extracellular signal regulated kinase signaling pathway. Endocrinology, n. 148, p. 530-537. DOI: 10.1210/en.2006-0763

KIM, H. W.; KNOWLES, J. C.; KIM, H. E. (2004) Development of hydroxyapatite bone scaffold for controlled drug release via poly( $\epsilon$-caprolactone) and hydroxyapatite hybrid coatings. J. Biomed. Mater. Res. Part B: Applied Biomater., v. 70, p. 240-249. DOI: 10.1002/jbm.b.30038

KARAGEORGIOU, V.; KAPLAN, D. (2005) Porosity of 3D biomaterial scaffolds and osteogenesis. Biomaterials, v. 26, p. 5474-5491. DOI: 10.1016/j.biomaterials.2005.02.002

MANO, J. F.; SOUSA, R. A.; BOESEL, L. F.; NEVES, N. M.; REIS, R. L. (2004) Bioinert, biodegradable and injectable polymeric matrix composites for hard tissue replacement: State of the art and recent developments. Composi. Sci. Technol., n. 64, p. 789-817. DOI:

10.1016/j.compscitech.2003.09.001

MIRSAYAR, M. M.; JONEIDI, V. A.; PETRESCU, R. V. V.; PETRESCU, F. I. T.; BERTO, F. (2017) Extended MTSN criterion for fracture analysis of soda lime glass, Engineering

Fracture Mechanics, n. 178, p. 50-59, ISSN: 0013-7944,

http://doi.org/10.1016/j.engfracmech.2017.04.018

MORALES-HERNANDEZ, D. G.; GENETOS, D. C.; WORKING, D. M.; MURPHY, K. C.; LEICH, J. K. (2012) Ceramic identity contributes to mechanical properties and osteoblast behavior on macroporous composite scaffolds. J. Funct. Biomat., v. 23, p. 382-397. DOI: 10.3390/jfb3020382

MOURIÑO, V.; CATTALINI, J. P.; BOCCACCINI, A. R. (2012) Metallic ions as therapeutic agents in tissue engineering scaffolds: An overview of their biological 
INDEPENDENT JOURNAL OF MANAGEMENT \& PRODUCTION (IJM\&P)

http://www.ijmp.jor.br

v. 11, n. 4, July - August 2020

ISSN: 2236-269X

DOI: 10.14807/ijmp.v11i4.950

applications and strategies for new developments. J. Royal Society Interface, v. 9, p. 401419. DOI: 10.1098/rsif.2011.0611

MONTHEARD, J. P.; CHATZOPOULOS, M.; CHAPPARD, D. (1992) 2-

hydroxyethylmethacrylate HEMA; chemical properties and applications in biomedical fields. J Macromol Sci Macromol Rev., v. 32, p. 1-34.

KABRA, B.; GEHRKE, S. H.; HWANG, S. T.; RITSCHEL, W. (1991) Modification of the dynamic swelling behaviour of pHEMA. J Appl Polym Sci, v. 42, p. 2409-16.

PELUSO, G.; PETILLO, O.; ANDERSON, J. M.; AMBROSIO, M.; NICOLAIS, L.; MELONE, M. A. B.; ESCHBACH, F. O.; HUANG, S. J. (1997) The differential effects of poly(2-hydroxyethylmethacrylate) and poly(2-hydroxyethylmethacrylate)/poly(caprolactone) polymers on cell proliferation and collagen synthesis by human lung fibroblasts. J Biomed Mater Res., v. 34, p. 327-36.

PERILLO, L.; SORRENTINO, R.; APICELLA, D.; QUARANTA, A. C.; GHERLONE, E. D.; FERRARI, M.; AVERSA, R.; APICELLA, A. (2010) Nonlinear visco-elastic finite element analysis of porcelain veneers: a submodelling approach to strain and stress distributions in adhesive and resin cement. The journal of adhesive dentistry, v. 12, n. 5, p. 403-413: ISSN: 14615185

PETRESCU, F. I. T.; CALAUTIT, K. J. (2016a) About Nano Fusion and Dynamic Fusion, Am. J. Applied Sci., v. 13, n. 3, p. 261-266.

PETRESCU, F. I. T. ; CALAUTIT, K. J. (2016b) About the Light Dimensions, Am. J. Applied Sci., v. 13, n. 3, p. 321-325.

PETRESCU, F. L.; BUZEA, E.; NĂNUT,, L.; NEACŞA, M.; NAN, C. (2015) The role of antioxidants in slowing aging of skin in a human, Analele Univers. Craiova Biologie Horticultura Tehn. Prel. Prod. Agr. Ing. Med., v. 20, p. 567-574.

PETRESCU, F. I. T.; APICELLA, A.; AVERSA, R.; PETRESCU, R. V.; CALAUTIT, J. K.; MIRSAYAR, M. (2016a) Something about the Mechanical Moment of Inertia, Am. J. Applied Sci., v. 13, n. 11, p. 1085-1090.

PETRESCU, R. V.; AVERSA, R.; APICELLA, A.; LI, S.; CHEN, G.; MIRSAYAR, M.; PETRESCU, F. I. T. (2016b) Something about Electron Dimension, Am. J. Applied Sci., v. 13, n. 11, p. 1272-1276.

PETRESCU, R. V.; AVERSA, R.; APICELLA, A.; BERTO, F.; LI, S.; PETRESCU, F. I. T. (2016c) Ecosphere Protection through Green Energy, Am. J. Applied Sci., v. 13, n. 10, p. 1027-1032.

PETRESCU, F. I. T.; APICELLA, A.; PETRESCU, R. V.; KOZAITIS, S. P.; BUCINELL, R. B.; AVERSA, R.; ABU-LEBDEH, T. M. (2016d) Environmental Protection through Nuclear Energy, Am. J. Applied Sci., v. 13, n. 9, p. 941-946.

PETRESCU, R. V.; AVERSA, R.; APICELLA, A.; PETRESCU, F. I. T. (2016e) Future Medicine Services Robotics, Am. J. of Eng. and Applied Sci., v. 9, n. 4, p. 1062-1087.

PETRESCU, F. I. T.; PETRESCU, R. V.; MIRSAYAR, M. M. (2017) The Computer Algorithm for Machine Equations of Classical Distribution. JOURNAL OF MATERIALS AND ENGINEERING STRUCTURES, v. 4, n. 4, p. 193-209.

http://revue.ummto.dz/index.php/JMES/article/view/1590

PETRESCU, F. I. T.; PETRESCU, R. V.; MIRSAYAR, M. M. (2018) Inverse Kinematics to a Stewart Platform. JOURNAL OF MATERIALS AND ENGINEERING 
DOI: 10.14807/ijmp.v11i4.950

STRUCTURES, v. 5, n. 2, p. 111-122.

http://revue.ummto.dz/index.php/JMES/article/view/1623

PETRESCU, F. I. T. (2019) About the nuclear particles’ structure and dimensions. Comp. Part. Mech., v. 6, p. 191-194, https://doi.org/10.1007/s40571-018-0206-7

REILLY D.; BURSTEIN A. H. (1974) The mechanical properties of cortical bone. The J. Of bone and Joint Surgery, v. 56A, n. 5, p. 1001-1021

REILLY D. T.; BURNESTAIN A. H. (1975) The elastic and ultimate properties of compact bone tissue. J. Biomechanics, v. 8, p. 393-405, doi:10.1016/0021-9290(75)90075-5

SCHIRALDI, C.; D’AGOSTINO, A.; OLIVA, A.; FLAMMA, F.; DE ROSA, A.;

APICELLA, A.; AVERSA, R.; DE ROSA, M. (2004) Development of hybridmaterials based on hydroxyethylmethacrylate as supports for improving cell adhesion and proliferation.

Biomaterials, v. 25, n. 17, p. 3645-3653.

SORRENTINO, R.; APICELLA, D.; RICCIO, C.; GHERLONE, E. D.; ZARONE, F.; AVERSA, R. E.; GARCIA-GODOY, F. F.; FERRARI, M.; APICELLA, A. (2009) Nonlinear visco-elastic finite element analysis of different porcelain veneers configuration, Journal of Biomedical Materials Research - Part B Applied Biomaterials, v. 91, n. 2, November, p. 727-736; DOI: 10.1002/jbm.b.31449 (10)

SORRENTINO, R.; AVERSA, R.; FERRO, V.; AURIEMMA, T.; ZARONE, F.; FERRARI, M.; APICELLA, A. (2007) Three-dimensional finite element analysis of strain and stress distributions in endodontically treated maxillary central incisors restored with different post, core and crown materials. Dent Mater, v. 23, p. 983-93: DOI: 10.1016/j.dental.2006.08.006

SCHWARTZ-DABNEY, C. L.; DECHOW, P. C. (2003) Variation in Cortical Material Properties Throughout the Human Dentate Mandible. American Journal of Physical Anthropology, n. 120, p. 252-277.

TÖYRÄSA, J; LYYRA-LAITINENA, T.; NIINIMÄKIB, M.; LINDGRENC, R.; NIEMINENB, M. T.; KIVIRANTAD, I.; JURVELINA, J. S. (2001) Estimation of the Young's modulus of articular cartilage using an arthroscopic indentation instrument and ultrasonic measurement of tissue thickness. Journal of Biomechanics, v. 34, n. 2, 251-256 WOLFF, J. (1892) Das Gesetz der Transformation der Knochen. Berlin: A Hirschwald. 